\title{
PENGARUH FREE CASH FLOW, PERTUMBUHAN PERUSAHAAN DAN KEBIJAKAN HUTANG TERHADAP DIVIDEND PAYOUT PADA PERUSAHAAN SEKTOR PERTANIAN YANG TERDAFTAR DI BEI PERIODE 2015 - 2019
}

\author{
${ }^{1}$ Ronaldo, ${ }^{2}$ Sri Elviani, ${ }^{3}$ Syamsul Efendi \\ ${ }^{1,2,3}$ Universitas Islam Sumatera Utara \\ ${ }^{1}$ ronaldopalem@gmail.com, ${ }^{2}$ srielviani@fe.uisu.ac.id, ${ }^{3}$ syamsul.efendi@fe.uisu.ac.id
}

\begin{abstract}
The purpose of this study is to observe the relationship between free cash flow, debt policy and company growth with dividend payout. The type of research data used is a quantitative approach. Determination of the sample that can be used is purposive sampling technique, and there are 10 companies in the agricultural sector that become the research sample from 25 companies as a whole. The analytical technique used is multiple linear regression. The data source used is secondary data obtained from the Indonesia Stock Exchange, by taking financial reporting data, from 2015 to 2019. The results of this study state that individually the company's growth has a negative effect on dividend payout, then free cash flow and debt policies do not have influence with dividend payout. Meanwhile, simultaneously free cash flow, debt policy and company growth have no effect on dividend payout.
\end{abstract}

Keywords : Free Cash Flow, Debt Policy, Company Growth, Dividend Payout

ABSTRAK : Tujuan penelitian ini yaitu, mengamati keterkaitan antara free cash flow, kebijakan hutang dan pertumbuhan perusahaan dengan dividend payout. Jenis data penelitian yang dimanfaatkan yaitu pendekatan kuantitatif. Penentuan sampel yang dapat dimanfaatkan yaitu teknik purpossive sampling, dan terdapat 10 perusahaan pada sektor pertanian yang menjadi sampel penelitian dari 25 perusahaan secara keseluruhan. Teknik analisis yang dimanfaatkan yaitu regresi linier berganda. Sumber data yang dimanfaatkan yaitu data sekunder yang didapatkan dari Bursa Efek Indonesia, dengan mengambil data pelaporan keuangan, tahun 2015 sampai 2019. Hasil penelitian ini menyebutkan bahwa secara induvidual pertumbuhan perusahaan memiliki pengaruh negatif dengan dividend payout, kemudian free cash flow dan kebijakan hutang tidak memiliki pengaruh dengan dividend payout. Sedangkan secara bersamaan free cash flow, kebijakan hutang dan pertumbuhan perusahaan tidak memiliki pengaruh dengan dividend payout.

Kata Kunci : Free Cash Flow, Kebijakan Hutang, Pertumbuhan Perusahaan, Dividend Payout

\section{Pendahuluan}

\subsection{Latar Belakang Masalah}

Menurut Riyanto (2011 : 268) dividend payout yaitu besarnya persentase keuntungan pada perusahaan, yang akan diberikan kepada para investor sebagai cash dividend. Dividend payout juga sering dimanfaatkan sebagai pengukuran bagi investor dalam melakukan penanaman modalnya. Proporsi dividen yang akan diberikan kepada para investor, sangat tergantung pada kemampuan perusahaan dalam memperoleh laba, sehingga menjadi suatu bentuk atas kebijakan dividen yang diterapkan perusahaan.

Free cash flow menjadi faktor utama yang dapat mendeteksi besar ataupun kecilnya dividen yang diberikan kepada para investor, karena menggambarkan tingkat fleksibelitas keuangan pada suatu perusahaan. free cash flow yaitu aliran kas pada suatu perusahaan, yang diberikan kepada pihak luar dan juga investor, yang tidak dimanfaatkan untuk modal kerja serta penanaman modal terhadap aset tetap. Perusahaan dengan aliran kas bebas yang berlebih, tentunya akan dapat menciptakan hasil kinerja yang baik, karena dapat memperoleh keuntungan atas kesempatan yang telah dilakukan, sehingga aliran kas bebas tersebut dapat dimanfaatkan untuk melakukan pembayaran dividen kepada para investor, pembayaran hutang kepada kreditur sebagai salah satu bentuk kewajiban yang harus dilaksanakan, maupun untuk akuisisi. 
Kebijakan hutang juga menjadi salah satu rasio yang dapat mendeteksi besarnya proporsi dividen yang akan diberikan kepada para investor, karena mencerminkan suatu kebijakan yang diambil perusahaan untuk melaksanakan pembiayaan terhadap hutang, guna menjalankan aktivitas operasionalnya. Kebijakan hutang dengan debt to equity ratio sebagai tolak ukurnya, memberikan suatu gambaran terhadap perbandingan antara modal pinjaman dengan ekuitas. Semakin besar hutang yang digunakan, maka semakin banyak angsuran pokok berupa bunga yang akan dibayar. Hal ini membuktikan bahwa permodalan usaha lebih banyak menggunakan dana pinjaman dibandingkan dengan ekuitas atau modal sendiri, sehingga sebagian kecil dari pendapatan tersebut yang akan diberikan sebagai dividen kepada para investor, dikarenakan sebagian besar pendapatan lainnya digunakan untuk melakukan pembayaran hutang kepada kreditur, sebagai kewajiban yang harus dilaksanakan oleh perusahaan.

Pertumbuhan perusahaan juga menjadi faktor yang dapat mempengaruhi besarnya proporsi dividen yang akan dibagikan kepada investor, karena mampu memberikan dampak yang baik terhadap perusahaan, serta pihak lainnya, seperti para investor dan juga kreditur. Perusahaan yang mempunyai pertumbuhan yang tinggi, dapat membuktikan bahwa perusahaan tersebut memliki keuntungan yang berlebih, sehingga dapat dimanfaatkan untuk membayarkan dividennya kepada para investor. Keuntungan tersebut dialokasikan untuk pertumbuhan perusahaan, sehingga membuat perusahaan tersebut akan meningkat, serta dapat memberikan keuntungan yang lebih pada tahun selanjutnya, dan proporsi dividen juga akan mengalami kenaikan (Devi, 2019).

\section{Tinjauan Pustaka}

\subsection{Dividend Payout}

Menurut Sudana (2011 : 167) dividend payout yaitu persentase keuntungan setelah pajak yang akan diberikan sebagai dividen kepada investor. Semakin tinggi dividen yang akan dibagikan, maka akan menguntungkan bagi para investor sendiri, namun juga akan menyebabkan kurangnya laba yang ditanam, sehingga perusahaan harus dapat mencari pendanaan eksternal, yaitu emisi saham yang baru. Dividend payout juga dapat dihitung dengan melakukan perbandingan antara dividen yang sudah diberikan dengan keuntungan pada lembar saham, dengan rumus berikut ini :

$$
\begin{aligned}
& \text { Dividend Payout }= \frac{\text { Dividend Per Share }}{\text { Earning Per Share }} \times \\
& 100 \%
\end{aligned}
$$

\subsection{Free Cash Flow}

Menurut Bringham \& Houston (2010 : 109) free cash flow yaitu aliran kas yang akan dibayarkan kepada investor, setelah perusahaan dapat melaksanakan penanaman modalnya terhadap aktiva tetap, yang dapat dimanfaatkan untuk dapat mempertahankan aktivitas operasionalnya. free cash flow memiliki tiga komponen yaitu arus kas operasi yang merupakan aliran kas yang didapatkan dari kegiatan perusahaan dalam melakukan penjualan, belanja modal yaitu selisih dari pembelian dengan penjualan aktiva tetap, dan modal kerja bersih yaitu selisih dari jumlah aktiva lancar dengan hutang lancar. Metode pengukuran free cash flow, dapat dinyatakan dengan rumus berikut ini :

\section{Free Cash Flow = Aliran Kas Operasi + Net Capital Service + Net Working Capital}

\subsection{Kebijakan Hutang}

Menurut Riyanto (2011 : 98) kebijakan hutang yaitu kebijakan yang penting pada suatu perusahaan, serta menjadi bagian dari kebijakan yang akan diambil oleh perusahaan. Salah satu metode pengukuran kebijakan hutang yang dapat dimanfaatkan yaitu debt to equity ratio, yaitu suatu penggambaran mengenai kemampuan ekuitas dalam menutupi hutang perusahaan kepada pihak eksternal. Perhitungan pada debt to equity ratio, dapat dilakukan dengan rumus berikut ini :

$$
\text { Debt To Equity Ratio }=\frac{\text { Total Hutang (Debt) }}{\text { Ekuitas (Equity) }}
$$

\subsection{Pertumbuhan Perusahaan}

Menurut Sudana (2011 : 162) pertumbuhan perusahaan dapat ditinjau dari hasil penjualan setiap tahunnya. Pertumbuhan perusahaan yaitu suatu penggambaran mengenai pertumbuhan aktiva yang dimiliki oleh perusahaan, yang diukur dari perbedaan jumlah aset secara keseluruhan setiap tahunnya. Tingginya tingkat pertumbuhan pada perusahaan, akan dapat memungkinkan penggunaan liabilitas yang tinggi, dikarenakan hasil keuntungan yang tinggi akan mampu menutupi liabilitas perusahaan. Rumus yang dimanfaatkan untuk 
menghitung pertumbuhan perusahaan, yaitu sebagai berikut :

$$
\begin{gathered}
\text { Company Growth }= \\
\frac{\text { Total Asset }(t)-\text { Total Asset }(t-1)}{\text { Total Asset }(t-1)}
\end{gathered}
$$

\section{Metode Penelitian}

\subsection{Populasi Dan Sampel}

Jumlah populasinya yaitu sebanyak 25 perusahaan pada sektor pertanian yang tercatat di Bursa Efek Indonesia. Penarikan pada sampel dapat dilakukan dengan cara memanfaatkan teknik purpossive sampling, yaitu suatu penentuan sampel berdasarkan pertimbangan ilmiah dan juga kriteria yang ditentukan oleh peneliti. Sedangkan jumlah sampelnya yaitu sebanyak 10 perusahaan pada sektor pertanian.

\section{Hasil Penelitian}

\subsection{Analisis Statistik Deskriptif}

Tabel 1. Analisis Deskriptif

Descriptive Statistics

\begin{tabular}{|l|r|r|r|r|r|}
\hline & $\mathrm{N}$ & \multicolumn{1}{|c|}{ Minimum } & Maximum & \multicolumn{1}{|c|}{ Mean } & Std. Deviation \\
\hline X1 & & - & 50794045510 & 111937501120 & 1627401526209, \\
& 50 & 19729680000 & 00 & 1,64 & 153 \\
X2 & & 00 & 2,21 &, 9280 &, 64739 \\
X3 & 50 &, 13 &, 41 &, 0630 &, 11786 \\
Y & 50 &,- 30 &, 9698 & 1,21767 \\
Valid N & 50 &, 03 & 5,71 & & \\
(listwise) & 50 & & & & \\
\hline
\end{tabular}

Sumber : Data SPSS, 2021

Pada hasil analisis dari data output di atas, menjelaskan bahwa jumlah data pada masing masing variabel yaitu sebesar 50 data. Hasil tersebut diperoleh dari jumlah sampel yang diteliti yaitu sebanyak 10 perusahaan, dengan jangka waktu atau observasi selama 5 tahun. Dari hasil pada data output di atas, juga disimpulkan bahwa :

a. Free Cash Flow $\left(\mathrm{X}_{1}\right)$ mempunyai nilai minimum yang berjumlah 1.972.968.000.000, nilai maksimum yang berjumlah 5.079.404.551.000, nilai mean yang berjumlah 1.119.375.011.201,64, dan standar deviasi yang berjumlah 1.627.401.526.209,153.

\subsection{Sumber Data}

Sumber data yang dapat dimanfaatkan adalah data sekunder, yaitu sumber data yang telah didapatkan secara tidak langsung. Data tersebut diperoleh dalam bentuk pelaporan keuangan yang telah dipublikasikan melalui Bursa Efek Indonesia.

\subsection{Teknik Pengumpulan Data}

Teknik pengumpulan data yang dimanfaatkan untuk mendapatkan informasi yang tepat adalah dokumentasi, yaitu pengumpulan data dengan memperoleh informasi dari pelaporan keuangan yang listing di Bursa Efek Indonesia, melalui situs www.idx.co.id.

\subsection{Teknik Analisis Data}

Teknik analisis yang digunakan adalah regresi linier berganda, yaitu analisa yang berfungsi untuk mengamati hubungan antara dua variabel independen atau lebih dengan variabel dependen. 


\subsection{Uji Parsial}

Tabel 2. Uji Parsial (Uji t)

Coefficients $^{\mathrm{a}}$

\begin{tabular}{|c|c|c|c|c|c|}
\hline \multirow[b]{2}{*}{ Model } & \multicolumn{2}{|c|}{$\begin{array}{c}\text { Unstandardized } \\
\text { Coefficients }\end{array}$} & \multirow{2}{*}{$\begin{array}{c}\begin{array}{c}\text { Standardize } \\
\mathrm{d} \\
\text { Coefficient } \\
\text { s }\end{array} \\
\text { Beta }\end{array}$} & \multirow[b]{2}{*}{$\mathrm{t}$} & \multirow[b]{2}{*}{ Sig. } \\
\hline & B & $\begin{array}{l}\text { Std. } \\
\text { Error }\end{array}$ & & & \\
\hline $\begin{array}{ll}1 & \text { (Constan } \\
\text { t) }\end{array}$ &,- 617 & ,236 & & $-2,611$ &, 012 \\
\hline $\mathrm{X} 1$ & $\begin{array}{r}6,908 \mathrm{E}- \\
14\end{array}$ & ,000 & ,091 & 638 & ,527 \\
\hline LN_X2 &,- 027 & 207 &,- 019 &,- 129 & 898 \\
\hline X3 & $-3,105$ & 1,494 &,- 297 & $-2,078$ & 043 \\
\hline
\end{tabular}

Pada hasil analisis dari data output di atas, maka peneliti akan menarik kesimpulan dengan melakukan perbandingan antara bandingkan nilai signifikansi (Sig.) dengan tingkat signifikansi yaitu sebesar $0,05(\alpha=5 \%)$, serta membandingkan nilai $t_{\text {hitung }}$ dengan $t_{\text {tabel }}$ yaitu sebesar 2,012. Pada berbagai perbandingan yang telah dilaksanakan, maka dapat ditarik suatu kesimpulan berikut ini :

a. Free Cash Flow memiliki hasil signifikansi sebesar 0,527>0,05 dan nilai $\mathrm{t}_{\text {hitung }}$ sebesar $0,638<2,012$. Maka dapat disebutkan bahwa Free Cash Flow tidak berpengaruh dengan Dividend Payout.

b. Kebijakan Hutang memiliki hasil signifikansi sebesar $0,898>0,05$ dan nilai $\mathrm{t}_{\text {hitung }}$ sebesar $-0,129<-2,012$. Maka dapat disebutkan bahwa Kebijakan Hutang tidak berpengaruh dengan Dividend Payout.

c. Pertumbuhan Perusahaan memiliki hasil signifikansi sebesar $0,043<0,05$ dan nilai $\mathrm{t}_{\text {hitung }}$ sebesar $-2,078>-2,005$. Maka dapat disebutkan bahwa Pertumbuhan Perusahaan berpengaruh serta memiliki nilai negatif dengan Dividend Payout.

\subsection{Uji Simultan}

Tabel 3. Uji Simultan (Uji F)

ANOVA $^{\mathrm{a}}$

\begin{tabular}{|c|c|c|c|c|c|}
\hline Model & $\begin{array}{l}\text { Sum of } \\
\text { Squares }\end{array}$ & df & $\begin{array}{c}\text { Mean } \\
\text { Square }\end{array}$ & $\mathrm{F}$ & Sig. \\
\hline $\begin{array}{ll}1 & \text { Regressio } \\
\mathrm{n}\end{array}$ & 7,061 & 3 & 2,354 & 1,610 &, $200^{\mathrm{b}}$ \\
\hline Residual & 67,256 & 46 & 1,462 & & \\
\hline Total & 74,317 & 49 & & & \\
\hline
\end{tabular}

Sumber : Data SPSS, 2021

Pada hasil analisis dari data output di atas, maka peneliti akan menarik kesimpulan dengan melakukan perbandingan nilai signifikansi (Sig.) dengan tingkat signifikansi yaitu sebesar $0,05(\alpha=5 \%)$, serta membandingkan nilai $\mathrm{f}_{\text {hitung }}$ dengan $\mathrm{f}_{\text {tabel }}$ yaitu sebesar 2,80. Pada berbagai perbandingan yang telah ditentukan, diketahui bahwa variabel independen yang meliputi Free Cash Flow, Kebijakan Hutang dan Pertumbuhan Perusahaan memiliki hasil signifikansi sebesar $0,200>0,05$ dan nilai $\mathrm{f}_{\text {hitung }}$ sebesar $1,610<2,80$. Maka disebutkan bahwa Free Cash Flow, Kebijakan Hutang dan Pertumbuhan Perusahaan tidak berpengaruh dengan Dividend Payout. 


\subsection{Uji Determinasi}

Tabel 4. Pengujian Determinasi

\begin{tabular}{|l|c|r|r|r|}
\hline Model & \multicolumn{1}{|c|}{ Model Summary } \\
\hline 1 &, $308^{\mathrm{a}}$ & R Square & $\begin{array}{c}\text { Adjusted R } \\
\text { Square }\end{array}$ & $\begin{array}{c}\text { Std. Error of } \\
\text { the Estimate }\end{array}$ \\
\hline
\end{tabular}

Pada hasil pengujian dari tabel di atas, maka dapat diketahui nilai determinasi atau disebut dengan $R$ Square sebesar 0,095, yang kemudian dihitung dalam satuan persen (\%), yaitu sebagai berikut :

$$
\text { KD : } 0,095 \times 100 \%=9,5 \%
$$

Dari hasil perhitungan tersebut, maka besarnya nilai pada koefisien determinasi ( $\mathrm{R}$ Square) sama dengan 9,5\%. Maka dapat dikatakan bahwa kemampuan variabel independen yang meliputi Free Cash Flow, Kebijakan Hutang dan Pertumbuhan Perusahaan dalam menerangkan variasi pada variabel dependen yaitu sebesar 9,5\%, sedangkan selebihnya yaitu 90,5\% dikaitkan oleh variabel lainnya diluar penelitian.

\section{Evaluasi}

\subsection{Pengaruh Free Cash Flow Terhadap Dividend Payout}

Hasil penelitian ini menyebutkan bahwa free cash flow tidak berpengaruh dengan dividend payout. Hal ini mengindikasikan besarnya jumlah free cash flow pada perusahaan, namun tidak digunakan untuk membagikan dividen kepada investor. Perusahaan yang mempunyai free cash flow yang besar akan cenderung melakukan penanaman modalnya secara berlebihan, daripada harus membayarkannya kepada para investor, yaitu berupa dividen yang tinggi.

Hal ini sesuai dengan referensi yang dinyatakan oleh Kieso (2015 : 212) yang menyebutkan bahwa free cash flow adalah jumlah arus kas dikresioner yang dimiliki oleh perusahaan untuk melaksanakan investasi atau penanaman modal tambahan, melunasi modal pinjaman dan melakukan pembelian terhadap saham treasury. Maka dapat dijelaskan secara umum bahwa free cash flow yang berlebih, tidak dimanfaatkan untuk melaksanakan pembayaran dividen kepada para investor.

\subsection{Pengaruh Kebijakan Hutang Terhadap Dividend Payout}

Hasil penelitian ini menyebutkan bahwa kebijakan hutang tidak berpengaruh dengan dividend payout. Hal ini mengindikasikan perusahaan yang mempunyai modal pinjaman yang tinggi, tidak akan mampu untuk mempengaruhi kebijakan perusahaan dalam melakukan pembagian dividen. Perusahaan akan terus melakukan pembagian dividen tunai kepada para investor, agar perusahaan masih dianggap memiliki prospek yang benar dimasa yang akan datang, dan investor akan tetap menanamkan modalnya.

Hal ini sesuai dengan referensi yang dinyatakan oleh Riyanto (2011 : 98) yang menyebutkan bahwa kebijakan hutang adalah suatu keputusan penting dalam perusahaan, serta menjadi bagian dari kebijakan terhadap pendanaan. Kebijakan hutang yaitu suatu keputusan yang akan ditentukan oleh manajemen, dengan tujuan untuk mendapatkan sumber pembiayaan terhadap perusahaan, agar dapat dimanfaatkan untuk mendanai kegiatan operasional pada perusahaan.

\subsection{Pengaruh Pertumbuhan Perusahaan Terhadap Dividend Payout}

Hasil penelitian ini menyebutkan bahwa pertumbuhan perusahaan berpengaruh serta memilik nilai yang negatif dengan dividend payout. Hal ini dapat mengindikasikan perusahaan yang mempunyai pertumbuhan yang baik setiap tahunnya, membuktikan bahwa perusahaan memiliki keuntungan yang lebih, namun tidak dimanfaatkan untuk melakukan pembagian dividen kepada para investor. Hal ini tentunya dapat memberikan sinyal negatif kepada para investor untuk melakukan investasi.

Hal ini sesuai dengan referensi yang dinyatakan oleh Sudana (2011 : 162) yang menyebutkan bahwa pertumbuhan perusahaan juga merupakan suatu penggambaran mengenai pertumbuhan aktiva yang dimiliki oleh perusahaan, yang diukur dari perbedaan jumlah aktiva secara keseluruhan setiap tahunnya. Tingginya tingkat pertumbuhan pada perusahaan, akan dapat memungkinkan penggunaan liabilitas yang tinggi, dikarenakan 
hasil keuntungan yang tinggi akan mampu menutupi liabilitas pada suatu perusahaan.

\subsection{Pengaruh Free Cash Flow, Kebijakan Hutang Dan Pertumbuhan Perusahaan Terhadap Dividend Payout}

Hasil ini menyebutkan bahwa free cash flow, kebijakan hutang dan juga pertumbuhan perusahaan secara bersamaan tidak berpengaruh dengan dividend payout. Hal ini mengindikasikan bahwa free cash flow digunakan untuk melaksanakan semua kewajibannya yang dimiliki oleh perusahaan, dengan tujuan untuk meningkatkan pertumbuhan pada suatu perusahaan, sehingga tidak berdampak secara langsung terhadap pembayaran dividen kepada para investor.

\section{Kesimpulan}

Tujuan penelitian ini yaitu, mengamati hubungan antara free cash flow, kebijakan hutang dan juga pertumbuhan perusahaan dengan dividend payout secara induvidual maupun bersamaan, pada perusahaan pertanian yang tercatat di Bursa Efek Indonesia (BEI) pada tahun 2015 sampai 2019. Pada hasil penelitian yang telah dilaksanakan, maka dapat ditarik suatu kesimpulan sebagai berikut:

a. Free Cash Flow secara induvidual tidak mempunyai pengaruh dengan Dividend Payout pada perusahaan dengan sektor pertanian yang tercatat di Bursa Efek Indonesia, tahun 2015 sampai 2019.

b. Kebijakan Hutang secara induvidual tidak mempunyai pengaruh dengan Dividend Payout pada perusahaan dengan sektor pertanian yang tercatat di Bursa Efek Indonesia, tahun 2015 sampai 2019.

c. Pertumbuhan Perusahaan secara induvidual mempunyai pengaruh negatif signifikan dengan Dividend Payout pada perusahaan dengan sektor pertanian yang tercatat di Bursa Efek Indonesia, tahun 2015 sampai 2019.

d. Free Cash Flow, Kebijakan Hutang dan Pertumbuhan Perusahaan secara bersamaan tidak mempunyai pengaruh dengan Dividend Payout pada perusahaan dengan sektor pertanian yang tercatat di Bursa Efek Indonesia, tahun 2015 sampai 2019.

\section{DAFTAR PUSTAKA}

Bringham F, E \& Houston, J. (2010). Dasar -
Kesebelas, Cetakan Pertama). Jakarta : Salemba Empat.

Devi, Novia Sandra. (2019). Pengaruh Investment Opportunity Set, Free Cash Flow, Kebijakan Hutang Dan Pertumbuhan Perusahaan Terhadap Kebijakan Dividen Pada Perusahaan Manufaktur Periode 2014 - 2017. Skripsi : STIE Perbanas Surabaya.

Istiningtyas, Roro Ayu. (2013). Analisis Pengaruh Free Cash Flow, Leverage, Profitability, Risk, Growth Dan Firm Size Terhadap Dividend Payout Ratio (Studi Empiris Pada Perusahaan Manufaktur Yang Listing Di Bursa Efek Indonesia Tahun 2007 - 2011). Skripsi : Universitas Diponegoro.

Kieso, Donald E, Jerry J, Weygant \& Terry D, Warfield. (2014). Intermediate Accounting IFRS Edition (2nd ed). United States Of America : Wiley.

Puspita, Helen. (2013). Pengaruh Profitabilitas, Pertumbuhan Perusahaan Dan Good Corporate Governance Terhadap Kebijakan Dividen. Skripsi : Universitas Kristen Satya Wacana Salatiga.

Ratnasari, P, S, P \& Purnawati, N, K. (2019). Pengaruh Profitabilitas, Likuiditas, Tingkat Pertumbuhan Perusahaan Dan Leverage Terhadap Kebijakan Dividen. E Jurnal Manajemen. Vol. 8, No. 10.

Riyanto, Bambang. (2011). Dasar - Dasar Pembelanjaan Perusahaan. Yogyakarta : BPFE.

Sudana, I Made. (2011). Manajemen Keuangan Perusahaan Teori Dan Praktik. Jakarta : Erlangga.

Suherman R, Lukman I \& Kusnadi. (2015). Pengaruh Free Cash Flow, Hutang Dan Tingkat Pertumbuhan Perusahaan Terhadap Kebijakan Dividen Pada Perusahaan Manufaktur Yang Terdaftar Di Bursa Efek Indonesia. Jurnal Magister Manajemen. Vol. 1, No. 2. 